\title{
Steroid Sulfatase of Human Leukocytes and Epidermis and the Diagnosis of Recessive X-linked Ichthyosis
}

\author{
Ervin H. Epstein, Jr., and Mary E. LeVenthal, Dermatology Unit of the \\ Medical Service, San Francisco General Hospital Medical Center, Department \\ of Dermatology, University of California, San Francisco, California 94110
}

\begin{abstract}
A B S T RAC T Patients with recessive X-linked ichthyosis, one of the inherited types of excessive stratum corneum cohesion, have deficient steroid sulfatase in fibroblasts grown from their dermis. Because of the expense and long period required to grow such cells, we have assayed this enzyme in peripheral blood leukocytes and found it to be undetectable in those from patients with this type of ichthyosis, but normal in those from patients with other hereditary or acquired types of ichthyosis. In addition, steroid sulfatase activity is less in leukocytes from women who are carriers of this disease than normal women, and this assay can be used to detect such carriers. Despite previous studies demonstrating that the gene for this enzyme escapes the inactivation of other Xchromosome genes, normal women have leukocyte steroid sulfatase activity only 1.3 times that of normal men, suggesting that some gene dosage compensation occurs.

Normal human epidermis, the tissue most affected clinically, also expresses steroid sulfatase activity. The epidermal enzyme is similar in its subcellular localization, its molecular size, and kinetically to that of placenta, leukocytes, and fibroblasts.
\end{abstract}

\section{INTRODUCTION}

Recessive X-linked ichthyosis. (RXLI) ${ }^{1}$ is a troublesome and relatively common disease, affecting 1 in 6,000 males. It was separated from autosomal dominant ichthyosis vulgaris in 1965 on the basis of pedigree analysis and clinical features (1). The latter include earlier age of onset, sparing of the palms and soles, prominent darker scales producing an unwashed ap-

Portions of this work have been published in abstract form in 1979, Clin Res. 27: 18A and in 1980, Clin. Res. 28: $21 \mathrm{~A}$.

Received for publication 8 September 1980 and in revised form 10 December 1980.

${ }^{1}$ Abbreviations used in this paper: $\left[{ }^{3} \mathrm{H}\right] \mathrm{DHEA},\left[{ }^{3} \mathrm{H}\right] \mathrm{de}-$ hydroepiandrosterone; [ $\left.{ }^{3} \mathrm{H}\right] \mathrm{DHEAS},\left[{ }^{3} \mathrm{H}\right]$ dehydroepiandrosterone sulfate; RXLI, recessive X-linked ichthyosis. pearance especially on the side of the neck, and the subsequently described corneal stippling (2). Although these findings permit clinical differentiation of groups of patients, it is often difficult to assign a diagnosis to an individual male patient. Unlike more severe forms, both ichthyosis vulgaris and RXLI have normal epidermal cell proliferation (3), and the derangement appears to be an impaired shedding of stratum corneum cells.

In 1978 , Shapiro et al. $(4,5)$ reported that fibroblasts grown from the skin of patients with RXLI have markedly deficient amounts of steroid sulfatase. This enzyme deficiency was first detected in the placenta and found to be an X-linked cause of low maternal urinary estrogen excretion but, until recently, no postnatal abnormalities had been known in male infants after such pregnancies (6). Independently, workers in the Netherlands also discovered that this enzyme is missing in patients with RXLI $(7,8)$.

Although diagnosis of steroid sulfatase deficiency can be made readily by fibroblast culture, this procedure is expensive and slow. Hence, we have assayed this enzyme in peripheral blood leukocytes of normal persons and of patients with RXLI. Because the enzyme is detected readily in leukocytes from normal persons or patients with other types of ichthyosis, but is markedly reduced in those from patients with RXLI, this permits rapid and simple diagnosis of the disease. We also have assayed the enzyme in normal human epidermis as a first step in a consideration of the pathophysiology of the disease.

\section{METHODS}

Fibroblast cultures. Fibroblasts were cultured from 4-mm punch biopsies of the skin of the buttocks of patients with ichthyosis compatible clinically and by pedigree analysis with the diagnosis of RXLI as well as from patients with several other diseases. Skin samples were minced, explants were grown in Dulbecco's modified Earle's medium with $20 \%$ fetal calf serum, and cells were passaged using the same medium with $10 \%$ fetal calf serum. For routine assay of steroid sulfatase, cells from confluent cultures in two $\mathrm{T} 75$ flasks were 
used, and for chromatographic analysis cells from six T 75 flasks were used. Cells were harvested by treatment with $1.5 \%$ trypsin at $22^{\circ} \mathrm{C}$ for $\sim 4 \mathrm{~min}$, collected by centrifugation, and washed once in growth medium. Fibroblasts known to be deficient in arylsulfatase A (metachromatic leukodystrophy) or arylsulfatase B (Maroteaux-Lamy syndrome) were obtained from the Human Genetic Mutant Cell Repository (lines GM 78 and 197 and GM 519, respectively) in Camden, N. J.

Leukocytes. Peripheral blood from patients with RXLI or other types of ichthyosis, relatives of patients with RXLI, and volunteers with no known abnormalities of maturation and shedding of the stratum corneum was drawn into heparinized plastic syringes or heparinized evacuated glass tubes, usually after overnight fasting. Blood $(10 \mathrm{ml})$ was mixed with $2 \mathrm{ml}$ of 5\% dextran T-500 (Pharmacia Fine Chemicals, Piscataway, N. J.) and $0.12 \mathrm{M} \mathrm{NaCl}$ in a plastic tube, and the erythrocytes were allowed to settle at $22^{\circ} \mathrm{C}$ for $45 \mathrm{~min}$. The supernate was removed, and leukocytes were harvested by centrifugation at $22^{\circ} \mathrm{C}$ at $400 \mathrm{~g}$ for $10 \mathrm{~min}$. The pellet was suspended briefly in $2.0 \mathrm{ml}$ of $0.03 \mathrm{M} \mathrm{NaCl}$ to lyse residual erythrocytes, $1.6 \mathrm{ml}$ of $0.31 \mathrm{M} \mathrm{NaCl}$ was added to restore isotonicity, and the leukocytes were collected by centrifugation at $400 \mathrm{~g}$ for $10 \mathrm{~min}$ and homogenized in $1.5 \mathrm{ml}$ of buffer as indicated below. Alternatively, fractions containing polymorphonuclear leukocytes or lymphocytes and monocytes were separated from peripheral blood by centrifugation on FicollHypaque for $40 \mathrm{~min}$ at $350 \mathrm{~g}$.

Epidermis. Human skin was obtained at surgical circumcision of newborns or mastectomy or abdominoplasty of adult women. The upper portion of the skin was separated using an electric dermatome set at $0.3 \mathrm{~mm}$. After heating to $56^{\circ} \mathrm{C}$ for $3 \mathrm{~min}$ in saline, the epidermis was peeled off the dermis.

Tissue preparation. Fibroblasts, leukocytes, or epidermis were homogenized in iced 0.014-M Tris buffer, $\mathrm{pH} 8.0$, using a Polytron PT-10 (Brinkmann Instruments Co., Westbury, N. Y.) with one or two 10-s bursts at maximal speed. Enzyme assays were performed on the homogenate, on the supernate remaining after centrifugation for $30 \mathrm{~min}$ at $12,000 \mathrm{~g}$ at $4^{\circ} \mathrm{C}$ (low speed supernate), on a pelleted fraction prepared by centrifugation of that low speed supernate for $60 \mathrm{~min}$ at $105,000 \mathrm{~g}$ at $4^{\circ} \mathrm{C}$ (microsomes), on material remaining in solution after centrifugation for $60 \mathrm{~min}$ at $105,000 \mathrm{~g}$ at $4^{\circ} \mathrm{C}$ (cytosol), or on material solubilized from microsomes by treatment with $0.02 \mathrm{M}$ Tris, $\mathrm{pH} 7.4$, containing $0.5 \%$ Miranol (a generous gift of the Miranol Chemical Co., Irvington, N. J.) and remaining soluble after centrifugation for $30 \mathrm{~min}$ at $105,000 \mathrm{~g}$ at $4^{\circ} \mathrm{C}(9)$. DNA was determined by the diphenylamine method of Burton as modified by Giles and Meyers (10).

Steroid sulfatase assay. Enzyme activity was measured by desulfation of $\left[{ }^{3} \mathrm{H}\right]$ dehydroepiandrosterone sulfate $\left(\left[{ }^{3} \mathrm{H}\right]-\right.$ DHEAS), as suggested first by Burstein and Dorfman (11). Enzyme solution or suspension $(0.15 \mathrm{ml})$ was mixed with $10 \mathrm{nM} 7-\left[{ }^{3} \mathrm{H}\right]$ DHEAS $(24 \mathrm{Ci} / \mathrm{mmol}$, New England Nuclear, Boston, Mass.) $(0.10 \mathrm{ml})$ and incubated at $37^{\circ} \mathrm{C}$ for $1 \mathrm{~h}$. At the end of incubation, the solution was chilled, $1.00 \mathrm{ml}$ benzene was added, and the contents were mixed by vortexing. The phases separated within $1 \mathrm{~min}$, and $0.60 \mathrm{ml}$ of the upper benzene phase was removed and added to $10 \mathrm{ml}$ of scintillation fluid (PCS, Amersham Corp., Arlington Heights, Ill.) for determination of the amount of $\left[{ }^{3} \mathrm{H}\right]$ dehydroepiandrosterone $\left(\left[{ }^{3} \mathrm{H}\right]-\right.$ DHEA) extracted. $\left[{ }^{3} \mathrm{H}\right]$ DHEAS was extracted with benzene before use each day to remove $\left[{ }^{3} \mathrm{H}\right] \mathrm{DHEA}$ formed nonenzymatically during storage. To correct for nonenzymatic desulfation and for solubility of substrate in benzene, $\left[{ }^{3} \mathrm{H}\right]$ DHEAS was incubated at $37^{\circ} \mathrm{C}$ for $1 \mathrm{~h}$ and chilled, benzene and enzyme preparation were added, and the amount of radioactivity extracted into benzene ("background") was sub- tracted from that detected in the active enzyme incubations. All incubations were performed in duplicate. Enzyme activity is expressed as picomoles of $\left[{ }^{3} \mathrm{H}\right] \mathrm{DHEAS}$ converted to benzene-soluble $\left[{ }^{3} \mathrm{H}\right]$ DHEA per hour per microgram DNA.

Agarose chromatography. A single $1.2 \times 100-\mathrm{cm}$ column containing agarose beads (Agarose A $1.5 \mathrm{~m}$, Bio-Rad Laboratories, Richmond, Calif.) was used. Samples of Miranolsolubilized enzyme (up to $1.8 \mathrm{ml}$ ) were applied to the column and eluted at $10.8 \mathrm{ml} / \mathrm{h}$ at $22^{\circ} \mathrm{C}$ with $0.5 \%$ Miranol, $0.02 \mathrm{M}$ Tris, pH 7.4. Effluent was monitored at $280 \mathrm{~nm}$ with a Beckman DB-GT spectrophotometer (Beckman Instruments, Inc., Fullerton, Calif.) and fractions of $1.8 \mathrm{ml}$ were collected. Bovine serum albumin (Sigma Chemical Co., St. Louis, Mo.), blue dextran (Pharmacia, Fine Chemicals), and $\left[{ }^{14} \mathrm{C}\right]-$ valine (New England Nuclear) were used as molecular size standards. Effluent was assayed for sulfatase activity using $\left[{ }^{3} \mathrm{H}\right]$ DHEAS at $\mathrm{pH} 7.4$ or nitrocatechol sulfate at $\mathrm{pH} 5.5$. For the latter, $0.70 \mathrm{ml}$ of effluent was mixed with $0.10 \mathrm{ml}$ of $0.08 \mathrm{M}$ nitrocatechol sulfate (Sigmal Chemical Co.) in $4 \mathrm{M}$ $\mathrm{Na}$ acetate, $\mathrm{pH} \mathrm{5.5}$, and incubated for $120 \mathrm{~min}$ at $37^{\circ} \mathrm{C}$. Desulfated product was measured by absorption at $515 \mathrm{~nm}$ after addition of $1.2 \mathrm{ml}$ of $1 \mathrm{M} \mathrm{NaOH}$. For the former, conditions were the same as for direct tissue assay except that the incubation was for 120 to $240 \mathrm{~min}$.

\section{RESULTS}

\section{Detection of steroid sulfatase in normal human epidermis and leukocytes}

Normal human epidermis, leukocytes, and separated polymorphonuclear leukocytes and lymphocytes-monocytes all express steroid sulfatase as determined by $\left[{ }^{3} \mathrm{H}\right] \mathrm{DHEAS}$ desulfation. Using the standard assay of $0.15 \mathrm{ml}$ of enzyme, unfractionated leukocytes isolated from $10 \mathrm{ml}$ of normal blood and homogenized in $1.50 \mathrm{ml}$ of buffer produced 1,000-2,000 cpm above background (background $\sim 25 \%$ of total $\mathrm{cpm}$ in $0.60 \mathrm{ml}$ benzene). Lineweaver-Burk analysis of experiments in which varying concentrations of DHEAS were used gave Michaelis constant $\left(K_{\mathrm{m}}\right)$ values for epidermal microsomes of $40 \mu \mathrm{M}$ (Fig. 1) and for leukocyte homogenates or Miranol extracts of 6 to $30 \mu \mathrm{M}$. These are similar to values of $20-40 \mu \mathrm{M}$ determined in our laboratory for placental homogenate, low speed supernate, microsomes, or Miranol extracts (data not shown), and of 4 to $80 \mu \mathrm{M}$ determined in various tissues by other laboratories (11-16). Enzyme activity per microgram DNA was approximately equivalent in placenta and leukocytes but 18 times less in epidermis.

To determine whether the enzyme is similar physically as well as kinetically in different tissues and to confirm the specificity of the assay, Miranol H2Msolubilized material was chromatographed on agarose. Material solubilized from low speed supernatant preparations of placentas or fibroblasts produced a single peak of steroid sulfatase eluting just before bovine serum albumin and peaks of nitrocatechol sulfate sulfatase eluting with and after bovine serum albumin. In addition to their substrate specificities, these three peaks were identified as steroid sulfatase, arylsul- 


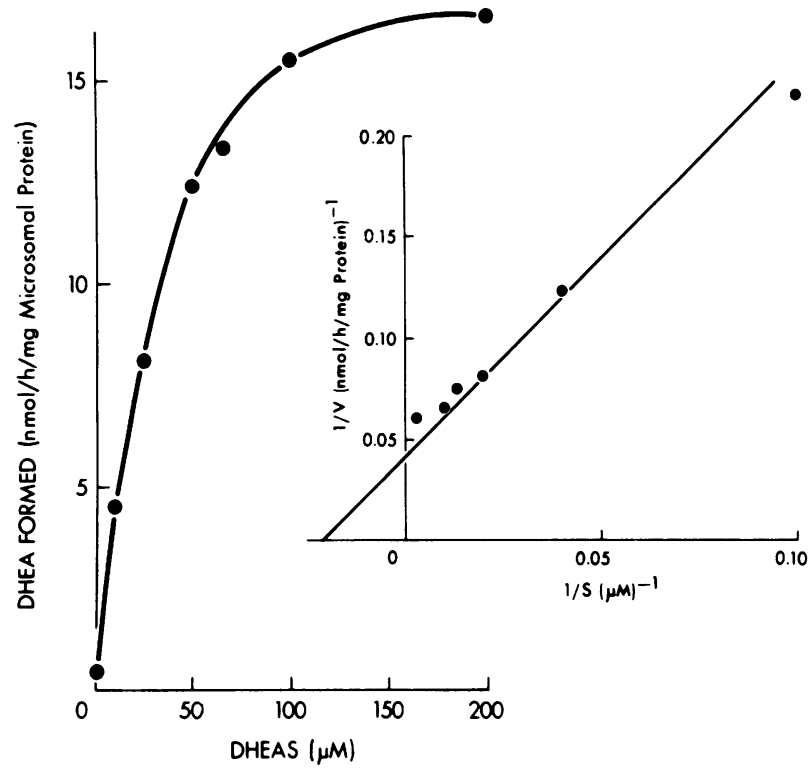

Figure 1 Desulfation of $\left[{ }^{3} \mathrm{H}\right]$ DHEAS by epidermal microsomes as a function of substrate concentration. Inset: Lineweaver-Burk analysis of data.

fatase A, and arylsulfatase B by their subcellular localization and their absence in mutant cell lines as follows.

Subcellularlocalization. The first but not the second or third peak was present in preparations solubilized from microsomes of placenta or epidermis (not shown) (steroid sulfatase is known to be present in microsomes), whereas the second and third peaks were present in preparations of cytosol (arylsulfatases A and $\mathrm{B}$ are known to be present in lysosomes).

Mutant cell lines. Only the first peak was absent in fibroblasts or leukocytes from patients with RXLI, only the second peak was absent in fibroblasts from patients with metachromatic leukodystrophy, and only the third peak was absent in fibroblasts from patients with the Maroteaux-Lamy syndrome, the last two being known to lack arylsulfatase A and arylsulfatase B, respectively. Steroid sulfatase from normal human epidermal microsomes or peripheral blood leukocytes (Fig. 2) eluted in the same volume as that from placenta or fibroblasts, suggesting that the enzyme was similar at least in molecular size in all four tissues. Furthermore, the lack of DHEAS desulfation by arylsulfatase A or arylsulfatase B (Fig. 2) suggested that these two sulfatases do not interfere in the DHEAS assay of steroid sulfatase.

\section{Diagnosis of $R X L I$}

Patients with RXLI were identified by pedigree analysis, clinical appearance, and in several instances by diminished fibroblast steroid sulfatase

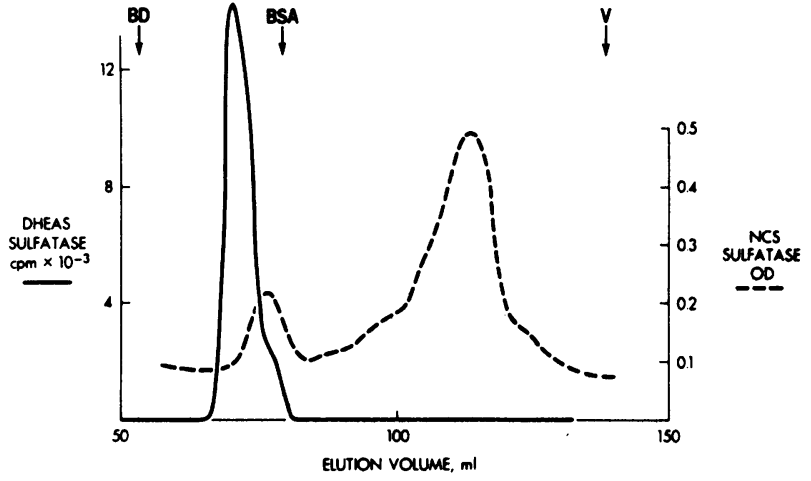

FigURE 2 Arylsulfatase elution from agarose chromatography of Miranol-treated leukocyte homogenate as detected by desulfation of $\left[{ }^{3} \mathrm{H}\right]$ DHEAS (solid line) and nitrocatechol sulfate (NCS) (dashed line). BD, BSA, and V mark the elution sites of blue dextran, bovine serum albumin, and $\left[{ }^{14} \mathrm{C}\right]$ valine, respectively.

activity. Steroid sulfatase activity also was absent in their unfractionated leukocytes (Fig. 3) as well as in polymorphonuclear leukocyte and lymphocyte-monocyte fractions from these patients. Activity was more variable in normal polymorphonuclear leukocyte and

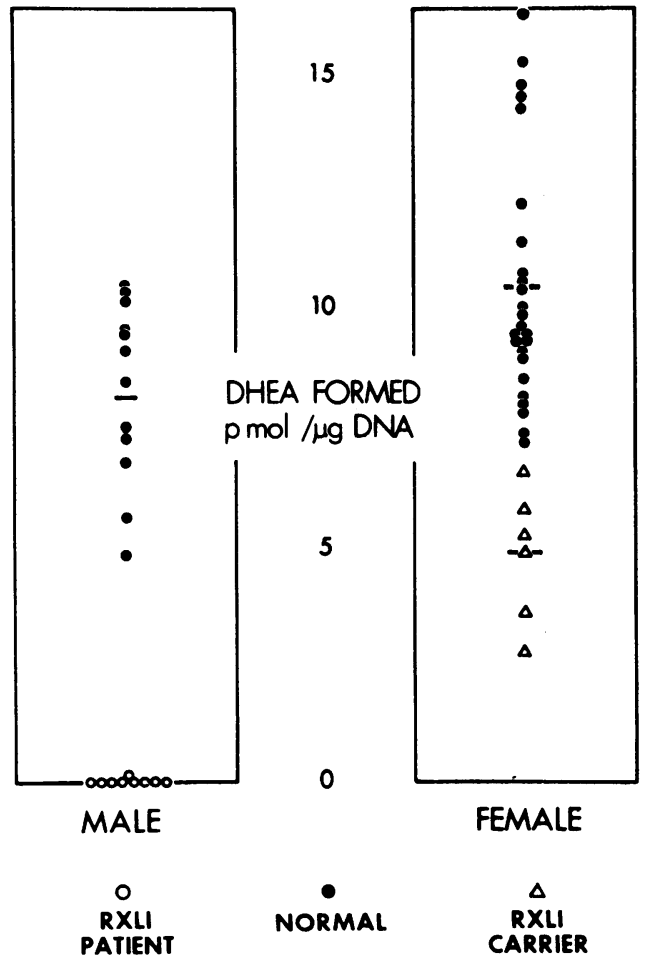

Figure 3 Desulfation of $\left[{ }^{3} \mathrm{H}\right]$ DHEAS by leukocytes from normal males or females (closed circles), patients with RXLI (open circles), and obligate carriers of the gene for RXLI (open triangles). Mean values for normal males and females and for obligate carriers are indicated by horizontal lines. 
lymphocyte-monocyte fractions isolated by FicollHypaque than in unfractionated leukocytes isolated by dextran sedimentation, and the latter was studied more carefully.

To estimate this variability, 12 replicate samples of unfractionated leukocytes from one normal male on each of $2 \mathrm{~d}$ were separately isolated, homogenized, and assayed for enzyme activity and DNA content. The mean values on the $2 \mathrm{~d}$ differed by $20 \%$, and the SD were 11 and $23 \%$ of the means on the $2 \mathrm{~d}$. In a separate experiment five leukocyte homogenates were assayed on the day of isolation and again after storage at $-20^{\circ} \mathrm{C}$ for $5 \mathrm{~d}$. Values for the second assay were 80 , $92,110,115$, and $117 \%$ of the first assay, suggesting a similar degree of variation and a stability of enzymatic activity under these conditions. The SD for samples from separate normal men and women were also $\sim 23 \%$ (see below).

Leukocyte steroid sulfatase was somewhat greater in normal women than men (mean values \pm SD: 10.2 $\pm 2.5 \mathrm{vs} .8 .0 \pm 1.8 \mathrm{pmol} / \mu \mathrm{g}$ DNA per $\mathrm{h}$, ratio $1.27: 1)$, but the overlap was great (Fig. 3). Enzyme activity $(4.7 \pm 1.5 \mathrm{pmol} / \mu \mathrm{g}$ DNA per $\mathrm{h})$ was significantly lower in leukocytes from females who were obligate carriers of the gene for RXLI-mothers or daughters of patients - than in normal females $(1: 2.2, P \leq 0.001)$ or normal males $(1: 1.7, P \leq 0.01)$. Leukocytes from one or more patients each with ichthyosis vulgaris, lamellar ichthyosis, epidermolytic hyperkeratosis, and acquired ichthyosis associated with Hodgkin's disease had normal steroid sulfatase activity. Enzyme activity still was detectable readily when blood was kept for $20 \mathrm{~h}$ at ambient temperature in an evacuated heparinized tube, but storage at $4^{\circ} \mathrm{C}$ caused marked diminution of activity.

\section{DISCUSSION}

These findings of steroid sulfatase deficiency are of interest for several reasons. First, measurement of leukocyte steroid sulfatase allows rapid differentiation of patients with RXLI from those with other types of ichthyosis and also permits identification of carriers of the gene, thereby enabling more accurate genetic counseling. Making a diagnosis more certain than that possible by clinical examination is likely to become increasingly important as newer therapeutic agents with varying effectiveness in different types of ichthyosis become available. Currently, 13-cis retinoic acid appears to be very useful for patients with lamellar ichthyosis, but of little benefit for patients with RXLI (17). Hence, definite diagnosis can obviate the need for a therapeutic trial with useless but potentially harmful agents. Although deficient steroid sulfatase activity can be detected in fibroblasts $(4,5,18,19)$, hair bulbs $(20$,
21), and calluses (20), detection in leukocytes appears to offer several advantages in cost and rapidity, ease of obtaining and processing samples, and the comparatively large amount of enzyme activity detected in normal persons. Furthermore, although there are conflicting reports of fibroblast steroid sulfatase levels in carrier females $(5,19)$, leukocyte steroid sulfatase levels seem sufficiently less than those of normal women to permit their identification with confidence. Because there is some daily variation in assay results, it is probably best to perform replicate assays of enzyme activity of possible carrier females and normal controls on the same day.

Recently, McNaught and France published evidence of solubilization of steroid sulfatase activity by Triton X-100 from microsomes of placentas of normal patients and also of patients with RXLI (22) and suggested that the defect in RXLI patients may be in the membrane rather than in the enzymatic protein itself. We, however, found that no enzymatic activity eluted from agarose when leukocytes from $120 \mathrm{ml}$ of blood from two patients with RXLI were studied under conditions in which 5-10\% of normal amount of enzyme would be expected to be detectable and in which equivalent peaks of arylsulfatase A were eluted from the normal and RXLI leukocyte preparations. Although they used a different detergent, it might be expected that Miranol would be more likely than Triton X-100 to remove phospholipids from the enzyme protein because our column appears to give narrower peaks at apparently lower molecular size.

Second, the presence of steroid sulfatase in normal human epidermis as well as its absence in callus of patients with RXLI (20) suggests that local action of this enzyme may be important in normal stratum corneum shedding. Although we have found considerably less enzymatic activity per microgram of DNA in the epidermis compared with that in leukocytes or placenta, it is possible that the enzyme may be distributed nonuniformly over the epidermis and hence may be present at high levels at discrete sites of action. The importance of lipids in stratum corneum properties has been suggested in the past by the ichthyosis of patients with Refsum's syndrome (23) and of patients treated with drugs that interfere with lipid metabolism (24). Experiments now are needed to determine whether sulfated sterols or steroids actually are increased in the stratum corneum of RXLI patients, whether such increase is specific to this particular type of scale or is a more common cause of faulty stratum corneum shedding, and whether the scaling is due to deficient enzyme action locally in the epidermis or is a consequence of deranged sulfated sterol-steroid metabolism elsewhere in the body. Although cholesterol sulfate has been noted to accumulate in tissues of pa- 
tients with the multiple sulfatase deficiency syndrome (25), no direct determinations of sulfated steroids and sterols in tissues of patients with RXLI have been reported.

Third, evidence from three groups suggests that, unlike other genes of the $\mathrm{X}$-chromosome, the gene for steroid sulfatase escapes the inactivation that normally occurs during early embryogenesis $(21,26-28)$. Nevertheless, we found only a small difference in leukocyte steroid sulfatase activity in females and males (1.27:1) with considerable overlap between the two groups, and heterozygote females had leukocyte steroid sulfatase activity considerably less than normal males. This suggests that some mechanism other than gene inactivation must effect compensatory reduction in levels of enzyme activity in women. We found a broad overlap between leukocyte steroid sulfatase activity in 20 menstruating and 5 postmenopausal women not receiving hormonal supplementation (not shown), and hence simple estrogen or progesterone modulation of enzyme activity is unlikely. Müller et al. (19) assayed steroid sulfatase in fibroblasts from normal women and men and, finding the mean level in women to be 1.7 times that in men, concluded that compensatory reduction does not occur. However, our findings in leukocytes should reflect more accurately the situation in vivo than would cultured fibroblasts, suggesting that the compensation may be a function of conditions specifically found in vivo. Supporting this suggestion is the finding of equal enzyme levels in hair bulbs from women and men (21). Furthermore, we found that leukocyte steroid sulfatase levels varied more in women than in men (Fig. 3), suggesting that compensatory reduction may occur to differing degrees in individual women. It is not known whether such compensatory control of enzyme activity acts by reducing the amount of enzyme protein present or by modulating the activity of what is present. Such control is likely to be the subject of further research.

\section{ACKNOWLEDGMENTS}

We are grateful to Dr. Mary Williams and Dr. Peter Elias for many helpful discussions and to them as well as to several other physicians for assistance in gathering patients and tissues: Drs. Wayne Chan, Michael Franzblau, Ronald Gruber, John Reeves, Diane Salyer, Melvin Schwartz, Samuel Stegman, Theodore Tromovich, and Arthur Ugel.

This work was supported by National Institutes of Health Research grant AM-18495. Some of these studies were carried out in the Clinical Study Center, University of California, San Francisco, with funds provided by the Division of Research Resources, GCRC-RR-83, U. S. Public Health Service.

\section{REFERENCES}

1. Kerr, C. B., and R. S. Wells. 1965. Sex-linked ichthyosis. Ann. Hum. Genet. 29: 33-50.
2. Sever, R. J., P. Frost, and G. Weinstein. 1968. Eye changes in ichthyosis. JAMA (J. Am. Med. Assoc.) 206: 2283-2286.

3. Frost, P. 1973. Ichthyosiform dermatoses. J. Invest. Dermatol. 60: 541-552.

4. Shapiro, L. J., R. Weiss, D. Webster, and J. T. France. 1978. X-linked ichthyosis due to steroid-sulphatase deficiency. Lancet. I: 70-72.

5. Shapiro, L. J., R. Weiss, M. M. Buxman, J. Vidgoff, R. L. Dimond, J. A. Roller, and R. S. Wells. 1978. Enzymatic basis of typical X-linked ichthyosis. Lancet. II: 756-757.

6. France, J. T. 1979. Steroid sulphatase deficiency. J. Steroid Biochem. 11: 647-651.

7. Jöbsis, A. C., C. Y. van Duuren, G. P. de Vries, J. G. Koppe, Y. Rijken, G. M. J. van Kempen, and W. P. de Groot. 1976. Trophoblast sulphatase deficiency associated with $\mathrm{X}$ chromosomal ichthyosis. Ned. Tijdschr. Geneeskd. 120: 1980 (Abstr.).

8. Jöbsis, A. C., W. P. de Groot, A. J. Tigges, H. W. A. de Bruijn, Y. Rijken, A. E. F. H. Meijer, and A. MarinkovicIlsen. 1980. X-linked ichthyosis and X-linked placental sulfatase deficiency: a disease entity. Am. J. Pathol. 99: 279-289.

9. Iwamori, M., H. W. Moser, and Y. Kishimoto. 1976. Solubilization and partial purification of steroid sulfatase from rat liver: characterization of estrone sulfatase. Arch. Biochem. Biophys. 174: 199-208.

10. Giles, K. W., and A. Meyers. 1965. An improved diphenylamine method for the estimation of deoxyribonucleic acid. Nature (Lond.). 206: 93 (Abstr.).

11. Burstein, S., and R. I. Dorfman. 1963. Determination of mammalian steroid sulfatase with $7 \alpha-\mathrm{H}^{3}-3 \beta$-hydroxyandrost-5-en-17-one sulfate. J. Biol. Chem. 238: 1656-1660.

12. Roy, A. B. 1957. The sulphatase of ox liver. 6. Steroid sulfatase. Biochem. J. 66: 700-703.

13. Notation, A. D., and F. Ungar. 1969. Regulation of rat testis steroid sulfatase. A kinetic study. Biochemistry. 8: 501-506.

14. Gill, W., and C. Chen. 1970. Dehydroepiandrosterone sulfatase in the prostate and seminal vesicles of the rat. Biochim. Biophys. Acta. 218: 148-154.

15. Payne, A. H. 1972. Gonadal steroid sulfates and sulfatase. V. Human testicular steroid sulfatase: partial characterization and possible regulation by free steroids. Biochim. Biophys. Acta. 258: 473-483.

16. Gant, N. F., L. Milewich, M. E. Calvert, and P. C. MacDonald. 1977. Steroid sulfatase activity in human fetal membranes. J. Clin. Endocrinol. Metab. 45: 965-972.

17. Peck, G. L., and F. W. Yoder. 1978. Treatment of disorders of keratinization with an oral stereoisomer of retinoic acid. In The Ichthyoses. Proceedings of the 2nd Annual Clinically Oriented Symposium of The European Society for Dermatological Research. R. Marks and P. J. Dykes, editors. SP Medical \& Scientific Books, New York. 193-202.

18. Kubilus, J., A. J. Tarascio, and H. P. Baden. 1979. Steroidsulfatase deficiency in sex-linked ichthyosis. Am. J. Hum. Genet. 31: 50-53.

19. Müller, C. R., B. Migl, H. Traupe, and H. H. Ropers. 1980. X-linked steroid sulfatase: evidence for different gene-dosage in males and females. Hum. Genet. 54: 197-199.

20. Baden, H. P., P. Hooker, J. Kubilus, and A. Tarascio. 1980 Analysis of keratinizing tissues for sulfatase deficiency. Clin. Res. 28: 562A (Abstr.).

21. Dancis, J., V. Jansen, and J. Hutzler. 1980. Gene dose compensation in X-linked ichthyosis. Pediatr. Res. 14: 521 (Abstr.). 
22. McNaught, R. W., and J. T. France. 1980. Studies of the biochemical basis of steroid sulphatase deficiency: preliminary evidence suggesting a defect in membraneenzyme structure. J. Steroid Biochem. 13: 363-373.

23. Davies, M. G., D. J. Reynolds, R. Marks, and P. J. Dykes. 1978. The epidermis in Refsum's disease (heredopathia atactica polyneuritiformis). In The Ichthyoses. Proceedings of the 2nd Annual Clinically Oriented Symposium of the European Society for Dermatological Research. R. Marks and P. J. Dykes, editors. SP Medical \& Scientific Books, New York. 51-64.

24. Simpson, G. M., J. H. Blair, and E. H. Cranswick. 1964. Cutaneous effects of a new butyrophenone drug. Clin. Pharmacol. Ther. 5: 310-321.

25. Murphy, J. V., H. J. Wolfe, E. A. Balazs, and H. W. Moser.
1971. A patient with deficiency of arylsulfatases A, B, C and steroid sulfatase, associated with storage of sulfatide, cholesterol sulfate and glycosaminoglycans. In Lipid Storage Diseases. Enzymatic Defects and Clinical Implications. J. Bernsohn and H. J. Grossman, editors. Academic Press, Inc., New York. 67-109.

26. Shapiro, L. J., T. Mohandas, R. Weiss, and G. Romeo. 1979. Non-inactivation of an X-chromosome locus in man. Science (Wash. D. C.). 204: 1224-1226.

27. Shapiro, L. J., T. Mohandas, R. S. Sparkes, and M. C. Sparkes. 1980. Expression of a human X-linked gene from an "inactive" $\mathrm{X}$ chromosome in somatic cell hybrids. Clin. Res. 28: 101A (Abstr.).

28. Müller, C. R., A. Westerveld, B. Migl, W. Franke, and H. H. Ropers. 1980. Regional assignment of the gene locus for steroid sulfatase. Hum. Genet. 54: 201-204. 